Article

\title{
Implementing a Sustainability Legacy Strategy: A Case Study of PyeongChang 2018 Winter Olympic Games
}

\author{
Hyung-Min Kim ${ }^{1} * *$ and Jonathan Grix ${ }^{2}$ \\ 1 Independent Researcher, Birmingham B31 2JG, UK \\ 2 Department of Economics, Policy and International Business, Manchester Metropolitan University, \\ Manchester M15 6BH, UK; j.grix@mmu.ac.uk \\ * Correspondence: feversing@gmail.com
}

Citation: Kim, H.-M.; Grix, J. Implementing a Sustainability Legacy Strategy: A Case Study of PyeongChang 2018 Winter Olympic Games. Sustainability 2021, 13, 5141 https://doi.org/10.3390/su13095141

Academic Editor: Seong Ok Lyu

Received: 1 March 2021

Accepted: 30 April 2021

Published: 5 May 2021

Publisher's Note: MDPI stays neutral with regard to jurisdictional claims in published maps and institutional affiliations.

Copyright: (c) 2021 by the authors. Licensee MDPI, Basel, Switzerland. This article is an open access article distributed under the terms and conditions of the Creative Commons Attribution (CC BY) license (https:// creativecommons.org/licenses/by/ $4.0 /)$.

\begin{abstract}
Given the growing need for hosts of sports mega-events to provide concrete plans for a sustainable sports mega-event at the bidding stage, it is perhaps surprising that there has not been more research on the actual implementation of the legacy plan in terms of sustainability. The main aim of this paper is to do just that: to analyse an empirical example of the implementation of the sustainability legacy plan for the PyeongChang 2018 Winter Olympic Games. Through an empirical analysis, the research methods used to collect the data are document analysis and semi-structured interviews with stakeholder sampling (16 documents and 10 interviewees). The paper uncovers the difficulties the PyeongChang Games encountered in achieving the sustainable legacy planned in the bid files through an evaluation of the implementation of PyeongChang's legacy strategy in the context of South Korea. Part of the findings reveal that Gangwon Province and South Korea achieved their strategic goals set out in advance of the PyeongChang Olympics as an effective tool for promoting regional development. One of the main obstacles to the sustainability of the PyeongChang Olympics was the lack of a clear plan for the post-Games use of Olympics venues and conflicts of interest among stakeholders of the PyeongChang Winter Games.
\end{abstract}

Keywords: Olympic legacy; sustainable development; triple bottom line; sports mega-event; Olympic Game impact; soft power

\section{Introduction}

In the contemporary era, sports mega-events are at the very core of the sports industry, creating value that is closely connected with many industries. They are also thought to have a wide range of impacts on the hosting venue, city and country [1,2]. Notwithstanding the wide range of benefits said to derive from hosting sports mega-events, competition among states to host sports mega-events has become less intense and has recently slowed. Many candidate cities for Olympics have cancelled their bids for the right to host the events following public referenda, due to concerns about the economic burden involved. This means that the variety of objectives and expected impacts of sports mega-events no longer appeal to countries that hope to host sports mega-events [3].

In order to overcome the limitations of sports mega-events, the International Olympic Committee (IOC) established sustainable development as their new pillar, following the existing two pillars of the Olympic mission: sport and culture. It means that the IOC's main concern has been changed, from sport and culture to environment and sustainable sport legacy [4]. Through Olympic Agenda 2020, the sustainability plan has become a significant phenomenon rather than a short-term trend [5]. The emergence of a sustainable legacy raises an essential issue of how to maintain long-term legacy after hosting sports megaevents. Given that the sustainability from sports mega-events has become an essential element, from the bidding stage to the closing ceremony, sustainability will not only have an essential role in the selection of the host countries, but the notion of sustainability itself is likely to be attractive to many countries seeking to host sports mega-events in future. 
The PyeongChang 2018 Winter Olympic Games were the first sports mega-event to be held in South Korea, which considered the Games' sustainability throughout its entire process. Since hosting the Seoul Olympics in 1988, Korea has developed and become one of the major sports powers in Asia, alongside China and Japan. The Games offered Korea a global platform to showcase their nation and contributed to the development of Korea economically, socially and politically [6]. Given that PyeongChang was chosen to host the Games on its third attempt, it is clear that PyeongChang's legacy plan for sustainability has been amended, modified and supplemented since their bid for the 2010 Winter Olympics. Previous evaluation reports from the IOC were positive about the sustainability plan for all three of PyeongChang's Olympic bids [7]. In that sense, PyeongChang's plan for a sustainable Olympic legacy can be seen as a more systematic and worked-through one than that of any other Olympics. It could be said that PyeongChang made a concrete plan for sustainable legacy in their bidding book.

A number of studies analysing the sustainability of sports mega-events have been conducted [8-13], but only a few studies have analysed the process of a host city's sustainable legacy plan in reality $[14,15]$. The main practical implication of the present study, therefore, is to provide future host cities with information to help create more realistic and practical plans for a sustainable legacy in their bid proposals. From this perspective, analysing the process of implementing the sustainability plan of the PyeongChang Olympics, from bidding book to actual implementation, would be an academic contribution to developing the sustainability of sports mega-events.

The main aim of this paper, therefore, is to investigate how to deliver a sustainable legacy from the PyeongChang 2018 Winter Olympic Games. It aims specifically to provide an analysis of actual outcomes in the implementation of a legacy strategy of sports megaevents from the sustainability standpoint and to illuminate the key obstacles in legacy strategy implementation.

\section{Literature Review and Theoretical Framework}

\subsection{Sports Mega-Events and Sustainability}

In response to the heightened awareness of the economic, social and environmental danger stemming from disproportionate development, the concept of sustainability has become significant from an integrated perspective [16]. The simultaneous desire for the balanced development of economic growth, a harmonious society and nature conservation has underpinned the widespread support for sustainability and has been addressed in wide-ranging academic discourse from many perspectives [17]. As Kidd [18] suggested, however, sustainability is not an emerging concept. The concept of sustainability has evolved over a long period of time. Kidd emphasised that the growing movement toward sustainability has been strongly influenced by different streams of thought that have moulded the concepts of sustainability. Although sustainability is not a one-dimensional concept related to the environment, in recent decades, it has frequently been considered as an environmental issue [19]. This means that when economic growth is carried out in order to meet human beings' basic needs, it should not exceed the environmental capacity of the ecosystem.

Broadly speaking, a major concern of the public is the economic impact that staging sports mega-events, such as the Olympic Games and the World Cup, will have on the hosting region and nation [20-22]. Previous researchers have also concluded that sports mega-events have an impact on urban regeneration [23-25], the enhancement of the soft power of the hosting state [26,27], Corporate Social Responsibility in sporting events [28,29], the destination image of the hosting venue as a tourist attraction [30,31], and a sense of pride in communities [32]. These various benefits of hosting SMEs could answer the question of why states invest in SMEs. However, there have been other concerns about negative impacts of sports mega-events such as exclusion of residents [33], high incidences of crime, vandalism, drunken behaviour, disorder and stealing [34-36], and environmental destruction [37]. As a movement for sustainability has grown up in the context of sports 
mega-events, the importance of candidate files for potential host cities-documents which contain their sustainability plans-has increased. The IOC's changes to its bidding procedure, in line with the new philosophy of Olympic Agenda 2020, incorporates the promise of sustainability through sports mega-events as an instrumental component in the bidding process [38]. The previous way of choosing the host country had become costly and drawn out, as well as complex bureaucratically [39]. The rationale behind sustainability in sport is to address the risk of sports mega-events that lack a clear vision and long-term action plan. Without a doubt, as a result of the unexpected expansion of the size of sports mega-event, called 'gigantism' [40], staging sports mega-events such as the Olympic Games or the World Cup requires not only huge government funding-drawn from public money for running the event and for investment in various venues and infrastructure-but also a continuous additional outlay on post-event management. The growing interest in sustainable event legacies notwithstanding, the lingering concerns of host cities about the long-term return on their investment have long overshadowed sports mega-events.

In order to host and manage sports mega-events effectively, candidate cities must consider appropriate national plans, with political support and public confidence for postevent management to avoid 'white elephants'. In Olympic Agenda 2020, the IOC expresses a strong commitment that future Olympic Games' bidding processes should break the pattern of low efficiency and high expenditure [5]. The IOC fills the first 5 of the 40 recommendations for the bidding process with a strong focus on sustainability and legacy. In terms of sustainability and positive legacy, the most eye-catching recommendation is that the IOC allows that the host city can hold entire sports or disciplines outside of the host city and, in exceptional cases, even outside of the host country [5]. These recommendations are very meaningful in that the IOC has changed its 'One-city Principle', for the first time allowing the Olympic Games to be co-hosted between two cities and countries. Through Olympic Agenda 2020, the IOC has made clear its commitment to reduce the total budget and expenses for the reason of sustainability in future Olympic bidding processes and in the operation of Olympic Organisations. For these reasons, the candidate cities for Olympic Games must submit their candidate files, including sustainability management plans for before, during and after the Games. Sustainable legacy from sports mega-events has also become an important assessment factor in ensuring the successful staging of sports megaevents in the host city and country from the long-term perspective, from the invitation phase, in which a potential city sets out its credentials, to the post-Games period. As a result, the main problem facing potential cities hoping to hold the sports mega-events has become the need present a long-term vision, with associated anxieties about what kind of sustainable legacy to leave through the sports mega-events.

In the past, there was huge gap between estimated budget and final operating budget to host sports mega-events. As the size of sports mega-events has increased, the soaring cost imposes financial burdens that candidate cities must bear. 100 percent of the sports mega-events, from 1960 to 2012, overran the costs set for their bidding phase, with final operating budgets 179 percent more on average than budgets at bid [41]. In fact, many European states have withdrawn a bid for the right to host sports mega-events for the reason of financial burden. In the bidding process for the 2022 Winter Olympic Games, which Beijing has won the right to host, four out of six candidate cities cancelled the bid as a result of referenda which resulted in a vote against their Olympic projects. Notably, voter turnout against a bid for hosting the Olympics in Krakow, Poland, was overwhelmingly high, at almost 70 percent [42]. MacAloon [3] describes the phenomenon of fewer countries interested in hosting the Olympics as a 'crisis'. Moreover, a majority of citizen living in Europe rejected Olympics bids. 
As sports mega-events have evolved into a multinational phenomenon in recent decades, they have developed the potential to be a strong catalyst for sustainability [43]. Given that research on sustainability in the context of sports mega-events tends to focus exclusively on just one aspect of sustainability (economic, social, or environmental), there has been lack of analysis of the sustainability legacies of sports mega-events which balances all three dimensions. The discourse around issues of sustainability in relation to the Olympic Games has mostly focused on the environmental dimension over the last few decades, reflecting the emphasis on this dimension in Olympic Agenda 21. However, Olympic Agenda 2020 has developed the understanding within the Olympic Movement that sustainability is a multidimensional concept. As shown by Toohey's research [44], the discussion of Olympic sustainability has been extended to the question of whether the Olympic Games can be held in the future or not. Moreover, many candidate cities for Olympics have cancelled their bids for the right to host the events following public referenda, due to concerns about the economic burden involved. It could be argued, therefore, that it is imperative that sustainability has been integrated into the plan for hosting sports mega-events across all phases [45].

There has been growing demand for concrete plans for hosting sustainable sports mega-events. As the first sustainable Winter and Summer Olympics, Vancouver 2010 and London 2012 have each delivered a wide range of sustainable legacies. The sustainable legacy of the Vancouver Olympics was planned and designed in the direction desired by the stakeholders through communication between various stakeholders [46]. For example, the community and the managing body participated in the design process of Olympic venues to deliver a sustainable legacy. Through the communication of these stakeholders, Vancouver's Olympic venues are still being used as community sports facilities for local residents or as training venues for elite sports. In addition, the Vancouver Olympics emphasised environmental sustainability and went along with Vancouver's Greenest City Action Plan [47]. The London Olympics had many impacts on increasing the benefits of the hosting city and contributing to the innovation of the national construction industry by utilising the Olympics as an opportunity for innovative construction projects. [48] In addition, East London, which had been dilapidated due to soil pollution and construction waste storage, was promoted as a 'sustainable urban renewal' case through the Olympics, contributing greatly to enhancing the image of the region [49]. As sustainability is a broad and complex concept, however, the sustainability plan for sports mega-events must always be adapted to the specific context of the host country. In addition, given that the principal objectives of sports mega-events are not decided by politicians alone, but have to reflect the interests and perspectives of various stakeholders [50], sustainability plans for sports mega-events should include step-by-step and concrete implementation strategies, which take specific local contexts into account, from the planning through to the impact evaluation stages.

\subsection{Triple Bottom Line as the Theoretical Framework}

The Triple Bottom Line (TBL) is used as the main theoretical framework to integrate and evaluate the sustainability of the PyeongChang 2018 Winter Olympic Games. The term 'triple bottom line' is an accounting framework that incorporates the three parts of sustainability, i.e., the economic, social and environmental aspects, coined in 1994 by John Elkington. The traditional usage of the financial term 'bottom line' is the final total profits and losses in the account of a company or organisation. It is also known as the 3Ps: Profit, People and Planet. According to Elkington [51] (p. 2), the triple bottom line refers to the approach of an organisation that focuses on 'economic prosperity, environmental quality and-the element which business has tended to overlook—social justice'. Savitz [52] (p. 8) also asserted that the triple bottom line 'captures the essence of sustainability by measuring the impact of an organisation's activities on the world. Including both its profitability and shareholder values and its social, human and environmental capital'. In line with this perspective, the triple bottom line approach has been adopted by many firms and 
organisations to report their sustainability. According to Deegan [53], the TBL is an important part of the operation of firms with regard to how they provide accountability to their stakeholders as well as carry out their sustainability performance. In essence, the TBL is a collaborative effort to reflect the three dimensions of sustainability, i.e., economic prosperity, social justice and environmental protection, into a firm's evaluation and decision-making processes through the recognition of the three bottom lines as fundamental elements of corporate management $[54,55]$.

First, the economic bottom line in the TBL refers to the impact of the practices of the business organisation on the economic system [51]. This bottom line has to do with the ability of the economy, one of the sub-systems of sustainability that can survive and evolve in the future, to support future generations [56]. In other words, the financial bottom line relates the growth of an organisation to economic growth and how well it contributes to supporting the economy. It emphasises the economic value that organisations provide to the surrounding systems, promoting and fostering their ability to meet the needs of future generations [57]. Second, the social bottom line means that the business organisation conducts beneficial and fair business practices with respect to labour, human capital and the region in which the company carries out its business [51]. The concept of the social bottom line is that fair and beneficial practices provide value to the communities in which the businesses operate, returning the profits to the community. Corporate social performance is related to the interactions between communities and organisations and responds to issues related to employee relations, fair wages and community involvement [58]. Social irresponsibility might have a negative impact on the company's business performance as well as an economic cost $[51,59]$. Finally, the environmental bottom line explains the impact that business practices have on the environment for future generations. It refers to effective methods for limiting the use of natural resources and the minimisation of the ecological footprint [51]. In order to efficiently implement resource conservation and eco-friendly strategies (greenhouse gas reduction, harmful chemical reduction, green production, etc.), the company should pursue an environmental health strategy through environmental regulations.

\section{Methodology}

This research utilises an empirical analysis, which is firmly rooted in the interpretivist position to explain social reality and phenomena. Interpretivism is an alternative epistemological assumption from positivism that 'is predicated upon the view that a strategy is required that respects the differences between people and the objects of natural sciences and therefore requires the social scientist to grasp the subjective meaning of social action' [60] (p. 17). The point of this approach is to gain an in-depth insight into the lives of the respondents, an empathetic understanding of why they act in the way that they do. In line with this perspective, Grix [61] argues that the interpretivism approach emphasises the role of both agents and structures.

In this study, two types of empirical data were collected. First, documents were collected and document analysis was selected as the method to provide a point of reference for understanding multiple views on the sustainable legacy policy making throughout the whole process of the Olympic Games. As one of the widely known means used to comprehend the meaning of social events and phenomena, document analysis has been a key method used in social research [62]. Document analysis can be widely used in both qualitative and quantitative research as a useful data source describing the social phenomena in which the documents are written [63]. May [64] stated that the analysis of official documents is also useful for understanding the meaning of power relations in society. In order to enhance the reliability and validity of the research, the document data were collected according to the following criteria: The first is through government documents published by the governments of hosting states, including documents published at the central and local level. The second is through official documents from the IOC and the 
Organising Committee for the Olympic Games of each hosting state. In total, 16 documents were analysed for this research.

Second, in-depth interviews were adopted for this study. This research method aims to answer the questions of 'why' and 'how' rather than 'how many' and 'when' [65]. Especially, the semi-structured interview technique was selected because it is useful for gaining insights into the decision-making process related to the PyeongChang 2018 Winter Games. It also helps provide an understanding and explanation of both the structure and agency aspects of the decision-making process regarding a sustainable legacy for the 2018 Winter Olympics, as the interviews allow information to be collected on the overall context as well as the process [64]. To overcome potential issues that may be involved when using interview methods, there has been a growing discussion in political science on the collection of data using the interview method from individuals in high positions who hold key positions or are key stakeholders over a period of time, also known as 'elites' [66]. Therefore, we adopted purposive and snowball sampling techniques for this study. Purposive sampling, also known as selective sampling, is useful to gather information about 'why particular people feel particular ways, [and] the processes by which these attitudes are constructed' [67] (p. 697). More specifically, stakeholder sampling was adopted among several purposive sampling techniques. This sampling is the most appropriate interview technique to collect data from stakeholders who have been or were involved in designing, giving, receiving, or administering in the context of policy analysis [67]. We attempted to interview stakeholders who were deeply involved in the PyeongChang Winter Games since the preparation of the bid book. With regard to the issue of reliability, the interviewees must fulfil one or more of the following criteria: (1) have been or were involved in the bidding committee to host the 2018 Winter Olympics; (2) have been or were involved in the PyeongChang Organising Committee for the 2018 Olympic and Paralympic Winter Games (POCOG); (3) be in a senior position within the relevant local or governing bodies; (4) be in a position of the strategic overview of an organisation which was involved in the bid process over the long term and (5) be a sports policy expert who could provide insights related to the sustainable legacy. In total, ten interviews were undertaken for this study. All interviews were conducted face-to-face by researcher in South Korea. The average age of interviewees was 48 and gender distribution was all male. The average number of years of experience in PyeongChang Winter Games and another sports mega-events held in South Korea was 9 years. The details of interviewees are outlined in Table 1.

Table 1. List of Interviewees.

\begin{tabular}{cccc}
\hline No & Position & Note & Interview Detail \\
\hline 1 & $\begin{array}{c}\text { Former governor of Gangwon } \\
\text { Province/Former president of } \\
\text { the POCOG }\end{array}$ & $\begin{array}{c}\text { Local government: } \\
\text { Gangwon Province }\end{array}$ & $\begin{array}{c}8 \text { May 2019 } \\
(1 \mathrm{~h} \mathrm{22} \mathrm{min})\end{array}$ \\
\hline 2 & $\begin{array}{c}\text { Secretary general and executive } \\
\text { Vice President the } \\
\text { POCOG/Deputy Minister }\end{array}$ & Central government & $\begin{array}{c}24 \text { May 2019 } \\
(1 \mathrm{~h} \mathrm{14} \mathrm{min})\end{array}$ \\
\hline 3 & $\begin{array}{c}\text { Vice president of the games } \\
\text { operations of the } \\
\text { POCOG/Former secretary } \\
\text { general }\end{array}$ & Central government & $\begin{array}{c}\text { 17 May 2019 } \\
(1 \mathrm{~h} \mathrm{31} \mathrm{min})\end{array}$ \\
\hline
\end{tabular}


Table 1. Cont.

\begin{tabular}{|c|c|c|c|}
\hline No & Position & Note & Interview Detail \\
\hline 4 & $\begin{array}{l}\text { Director budget and marketing } \\
\text { of the Korean Sport \& Olympic } \\
\text { Committee }\end{array}$ & Central government & $\begin{array}{l}9 \text { May } 2019 \\
(58 \mathrm{~min})\end{array}$ \\
\hline 5 & $\begin{array}{l}\text { Former Gangwon provincial } \\
\text { manager for the PyeongChang } \\
\text { Olympics/Head of peace } \\
\text { regional development division of } \\
\text { Gangwon Province }\end{array}$ & $\begin{array}{l}\text { Local government: } \\
\text { Gangwon Province }\end{array}$ & $\begin{array}{l}7 \text { May } 2019 \\
(55 \mathrm{~min})\end{array}$ \\
\hline 6 & $\begin{array}{c}\text { Former Head of knowledge } \\
\text { management team of the } \\
\text { POCOG }\end{array}$ & Sport expert & $\begin{array}{l}11 \text { May } 2019 \\
(1 \text { h } 7 \text { min })\end{array}$ \\
\hline 7 & $\begin{array}{c}\text { Manager of Olympic legacy team } \\
\text { of the POCOG }\end{array}$ & $\begin{array}{l}\text { Local government: } \\
\text { Gangwon Province }\end{array}$ & $\begin{array}{l}16 \text { May2019 } \\
(53 \mathrm{~min})\end{array}$ \\
\hline 8 & $\begin{array}{l}\text { Manager of city relation team of } \\
\text { the POCOG/Former manager } \\
\text { sustainability of the POCOG }\end{array}$ & Sport expert & $\begin{array}{l}15 \text { May } 2019 \\
\text { (51 min) }\end{array}$ \\
\hline 9 & $\begin{array}{l}\text { Former Olympic venue manager } \\
\text { in Gangwon Province }\end{array}$ & $\begin{array}{l}\text { Local government: } \\
\text { Gangwon Province }\end{array}$ & $\begin{array}{l}1 \text { June } 2019 \\
\text { (1 h } 2 \text { min) }\end{array}$ \\
\hline 10 & $\begin{array}{c}\text { Manager of Olympic legacy team } \\
\text { of the Gangwon Province }\end{array}$ & $\begin{array}{l}\text { Local government: } \\
\text { Gangwon Province }\end{array}$ & $\begin{array}{l}3 \text { June } 2019 \\
\text { (49 min) }\end{array}$ \\
\hline
\end{tabular}

In this study, all documents were converted to PDF format and imported by NVivo 12 for analysis. In addition, the documents used in this study were used to triangulate data with other data (e.g., in-depth interviews). The initial data from these documents were also helpful for feeding into and designing basic interview questions (see Appendix A). All interview questions were originally created by the researcher to analyse the sustainability of the PyeongChang Olympics. All the themes used in the interview question were from the TBL framework (economic, social and environmental sustainability), based on the initial document data. Those interview questions were open-ended to gain maximum data from the interview [68]. In this sense, document analysis is not adopted as an independent tool, but in the process of 'back-and forth interplay with the data' [69] (p. 37). The second type of data is from semi-structured interviews. In this study, thematic analysis, the most common technique among content analysis techniques, was adopted. This is an analysis that finds, analyses, and reports patterns of collected data, which not only provide new insights, but also improves researchers' understanding of specific social phenomena or actual actions [70]. All interview data obtained through the interview were uploaded to NVivo 12, a qualitative research coding program. During the interview, all interview conversations were recorded with the consent of the interviewees. All data from documents and interview were largely classified into three main categories-economic, social and environmental legacy - based on the framework of this study, the triple bottom line. The data within the themes had to be interconnected meaningfully, while care was taken to ensure clear and identifiable distinctions between the themes.

\section{Results}

\subsection{PyeongChang Winter Games and Sustainable Legacy Aims}

First, on the economic front, the 2018 PyeongChang Winter Olympics sought to be a catalyst for reviving the depressed economic situation in Gangwon Province [71]. The priority of Gangwon Province was to develop the province into an Asian winter sports and logistics hub, and thus encourage its economic growth [72]. As many past sports mega-events show, hosting international mega-sporting events has justified the use of taxpayers' money in social capital and infrastructure construction [73]. In line with this 
perspective, the PyeongChang bid hoped that the construction of winter sport facilities and infrastructure for the Winter Games would provide the opportunity for PyeongChang and Gangwon Province to develop into a winter sports hub in Asia. In addition, the development of the transportation infrastructure was expected to facilitate geographically dispersed inter-regional links in the Gangwon province. In order to achieve those economic legacy aims, Gangwon Province sought to: (1) expand its transportation infrastructure and (2) secure post-Games use of Olympic facilities.

Second, Gangwon Province tried to leave a social legacy through the hosting of the Olympic Games. The focus was on building social capital for residents of Gangwon Province through the successful hosting of the PyeongChang Olympics. It also sought out economic growth on the basis of improving regional identity in Gangwon Province, which was lowered due to geographical and political restrictions. Fredline [74] emphasised that hosting sports mega-event may positively impact on local residents' the sense of pride. The PyeongChang bid also sought to establish that the 2018 Winter Olympics would contribute to the development of winter sports in South Korea. To overcome this disproportionate balance, the Republic of Korea sought to maintain and strengthen its performance in ice sports, but also to provide diverse support for the other winter sports disciplines through the 6-year sports development plan called 'Drive the Dream II' [75]. In addition, Gangwon Province, the only region in South Korea to be divided during the civil war between the two Koreas, also sought to open the door for inter-Korean exchanges through the hosting of the PyeongChang Olympics. South Korea expected that easing inter-Korean conflicts through sports - a form of 'sports diplomacy' - would be in line with the ultimate goal of the Olympics, as well as an opportunity to ease strained inter-Korean relations due to North Korea's nuclear development.

Finally, PyeongChang hoped that the 2018 Winter Olympics would raise the bar for future sports mega-events in terms of the environmental focus. In order to actualize the Olympic Movement of eco-friendly Olympics, which is the trend of the Olympic Games, and deliver environmental legacies through the Olympics, the PyeongChang Olympics planned and pursued the best-ever eco-friendly Green Olympics [76]. In this context, Gangwon Province sought to protect its original clean resources. In pursuit of the $\mathrm{O}_{2}$ Free Olympics, it planned to minimize carbon emissions, and to minimize greenhouse gases, the main culprit of global warming and climate change. It also planned to minimize environmental damage due to the construction of stadia and infrastructure.

\subsection{Evaluation of the Implementation of the Economy Legacy}

First, the post-Games use of the PyeongChang Olympic venues was not implemented as planned at the bidding stage. Design changes to the PyeongChang Olympic venues occurred frequently during the preparation period of the Games. In the bid file, the POCOG set a plan to build 6 new Olympic venues and reuse seven existing venues. However, there was no mention of the PyeongChang Olympic Stadium, where the opening and closing ceremonies were performed, in its bid file. As one interviewee stated:

With a variety of problems, the IOC Evaluation Commission pointed out the problems from the first and second bid and suggested that a number of complementary measures are needed. In response, we decided that we would come up with an alternative plan to host the Olympics most effectively after confirmation as the host city. (Interviewee 02, 2019).

As advised by the IOC Evaluation Commission, it was decided to build the Olympic Stadium at Hoenggye Training Centre, which is two kilometers from Alpensia Ski Jumping Centre. The Olympic Stadium was only built as a temporary and 'pop-up' facility and most of the facilities were removed after the Olympics, except for the Medal Plaza. The Olympic Stadium was used for only four days for the opening and closing ceremonies of the PyeongChang Olympics and Paralympics. Considering the KRW 119.3 billion (USD 107.5 million) budget spent on the Olympic Stadium (from the purchase of the site to the demolition 
cost), the daily usage fee was approximately KRW 29.5 billion (USD 26.6 million) (Interviewee 02, 2019).

In the case of Gangneung Hockey Centre, located in the Gangneung Coastal Cluster, the post-Games use of the venue has not been decided after several changes. On the bid file, Gangneung Hockey Centre was intended to be a removable structure and moved to Wonju after the closing of the Olympics. One of the interviewees, who was involved in all three bids to host the PyeongChang Olympics, said that:

At the time of PyeongChang's first bid, the hockey centre was supposed to be built in Wonju, but the plan was modified to build the hockey stadium in Gangneung to host the compact Olympics. However, the Korea Ice Hockey Association made a proposal about the hockey stadium in Wonju as an Olympic legacy. After discussion, the hockey centre was built in Gangneung as planned, but was to be reduced to around 3000 seats after the Olympics to move to Halla University in Wonju to be used as a venue for ice hockey (Interviewee, 01).

However, the Gangneung Hockey Centre was unable to find proper utilization after the Olympics and it was decided to remove it in June 2014 under an agreement between the Ministry of Culture, Sports and Tourism, Gangwon Province and the POCOG. After two years, the PyeongChang Olympic Support Committee decided that Gangneung Hockey Centre, which was designed to be moved at the time of construction, should remain permanently at the current location in 2016. After that, in 2016, Daemyung Group, which owns the ice hockey team, decided to use Gangneung Hockey Centre as the home stadium for their own ice hockey team for 5 years after the closing of the Olympics. However, Daemyung Group gave up the operation due to its negative image of being involved in a political scandal and the operational cost of KRW 10 billion (USD 9 million) for five years [77]. As of 2020, the Hockey Centre is under the management of Gangwon Province for winter sports team training and competitions unlike the original plan.

Gangneung Oval was also originally planned to be used as a permanent ice rink under the management of Gangneung local government. However, the demolition and maintenance of the Olympic venue were reversed twice and it was finally earmarked to remain like the Gangneung Hockey Centre. The sliding centre also fails to use the original post-utilization plan and does not have a managing body. After the PyeongChang Olympic Foundation was established, Gangneung Hockey Stadium, Gangneung Oval and Alpensia Sliding Centre were to be managed by the foundation, but questions still remain about their usability and economic feasibility (Interviewee 04, 2019).

Second, the lack of communication among the Olympic stakeholders is a factor that impedes the delivery of the PyeongChang Olympics' sustainable economic legacy. Following the announcement of Agenda 2020, the PyeongChang Olympics had the potential to become the first Olympic venue to be no longer intertwined with the 'One-city Principle'. In line with this perspective, there were discussions on the sharing of venue-locations with other cities from late 2014. The characteristics of the Winter Games has led to high construction costs for Olympic venues while the demand for winter sports is quite low in South Korea.

As an alternative, the IOC proposed a venue-sharing plan with other countries for the PyeongChang Olympics from the sustainability standpoint. The main topic of the proposal was the venue-sharing of the sliding centre for reasons of geography and sustainability [78]. As a result, Asia's only sliding centre built during the 1998 Nagano Winter Olympics was strongly suggested as an alternative. Another alternative was to hold ice skating events in Seoul, the capital of South Korea, to reduce costs through the reuse of existing facilities. It was argued that given the densely populated region of Seoul, the post-Games use of the stadiums could be easily solved. According to Yoon [79], the budget saving from hosting two ice events in Seoul was KRW 113.7 billion (USD 102.5 million), and if four events were held in Seoul and another Province, the total budget saved could be KRW 372 billion (USD 
335.4 million). However, Park Geun-hye, who was President of South Korea at that time, stated that it is meaningless to discuss splitting the events of the PyeongChang 2018 Winter Games across a range of locations because work on the venues is already under way [80]. In fact, construction of the sliding centre for the PyeongChang Olympics began in October 2013. Construction of the three ice skating venues, located in Gangneung also began in June 2014 [81].

In addition, the lack of communication among stakeholders has also increased additional spending on the construction of Olympic facilities, which was not in the PyeongChang bid file. The largest part of the Olympic costs is the construction of Olympic venues and facilities except for non-sports related capital costs. Since these parts of the construction are paid in full by taxes and taxpayers (national tax 75 percent, local tax 25 percent), completing the construction as planned is a way to increase the economic sustainability of the Olympics. A member who participated in the Olympics as a public official in Gangwon Province noted:

Many International Sports Federations (IFs) participated in the Olympics to make sure that the facilities in the Olympic venue meet international standards in the best condition. There are many requirements to meet international standards, but we should comply with the IFs' requests. However, in the case of some stadiums, structural faults were discovered and asked to be corrected several times, even though the IFs participated in the construction process. This is a part that doesn't exist in the bid files, so it caused the rise in the cost of the PyeongChang Olympics (Interviewee 09, 2019).

One of the interviewees, who worked as Vice President of the Games Operations of POCOG, also emphasized that various consultations should take place from the Olympic bid stage as below:

Although Gangwon worked with the IFs from the design stage, some IFs required modifications from the beginning of construction. However, some IFs required modifications at the end. Even though Gangwon built the Olympic venues according to the IFs' standards, water leaked from the PyeongChang hockey rink and the curling sheet was not flat... To prevent this from happening, it's better to cooperate with the sports experts or IFs from the stage of the Olympic bid for advice. (Interviewee 5, 2019).

The construction of various Olympic venues is not limited to POCOG or Gangwon as a host venue. However, it is a comprehensive project that reflects the opinions and requirements of various stakeholders. Therefore, to achieve the optimized construction promotion system requires active communication between all stakeholders, including the IOC, IFs, host cities and organizing committees. In addition, sports experts, venue managers, sports managers, functional area members, stadium experts, host city officials, etc., must form an organizational cooperative system to leave a sustainable economic legacy.

In the bidding process for the PyeongChang Olympics, communication was lacking between the central government and Gangwon Province. As Gangwon Province became the main body to push for the Olympics, there was a lack of communication among stakeholders in the process of setting up advance plans in bid files and the financial guarantee of the central government.

The advance planning was the most important thing in the bid file. After the central government and Gangwon Province had enough discussion, it had to be approved by the central government. They should have gone through enough discussion. The PyeongChang Olympics was a bit weak in that area. Gangwondo planned the Olympics from the very beginning, and the central government agreed to underwrite it to the IOC without going over the details. Well, hosting the Olympics was the most urgent thing at that time (Interviewee 06, 2019).

Finally, there have been conflicts between the central and local governments over the funding. In the case of sports-related capital costs such as the construction cost for 
Olympics venues and support facilities, it was decided that the construction cost was to be subsidized by central government by at least 75 percent through the Special Act on Support for the Winter Olympics and the remaining 25 percent by Gangwon Province as stated in Article 35 of the law [82]. In other words, the IOC demands a firm financial guarantee from the national government when submitting a bid file. The bid files for hosting the 2010 and 2014 Winter Olympics meant that Gangwon Province would provide 50 percent of the financial guarantees and the central government would support 50 percent of the games [83]. However, in PyeongChang's third bid, the phrase relating to the financial guarantee of central government was replaced with a vague expression 'The National Government has assured its role as the ultimate guarantor in the event of any financial shortfalls incurred by POCOG' [71] (p. 106). The interviewee, who worked as the first chairman of the POCOG, said:

We had a hard time getting ready for the Olympics because the state subsidy rate was not decided. It's quite a contradiction to provide 30 percent from national subsidies for PyeongChang Olympics just like any other international events. In the end, the special law allowed the government to sharply increase its financial support from 30 percent to 75 percent, reducing the financial burden on Gangwon Province (Interviewee 01, 2019).

The conflict between the central government and Gangwon Province continued even after the closing of the PyeongChang Olympics. The central government and Gangwon Province also differed on the cost of using the remaining Olympic venues as an economic legacy after the closing of the Olympics. The post-Games use of the three Olympic venues (Alpensia Sliding Centre, Gangneung Hockey Centre and Gyeongpo Oval) is also a controversial issue between central government and Gangwon Province. As one interviewee from Gangwon Province noted:

The President said that the central government would take some responsibility for the costs of post-use of the stadium in order to reduce the financial burden of Gangwon Province. However, the central government is sitting on its hands now ... Anyway, the Olympic venues were built with 75 percent from national subsidy and 25 percent from the Gangwon Province budget, then rented to the POCOG and returned to the Gangwon facility at the end of the Olympics. If the central government does not fund the post-use of the venues, Gangwon has no choice but to take care of everything (Interviewee 02, 2019).

The lack of such legacy management plans and the officials' continued passing of the matter between central and local governments have tarnished the meaning of the Olympic legacy. The total operating cost of the three Olympic venues, whose use has still not been decided, is estimated to reach KRW 10.2 billion (USD 9.1 million) a year [84]. As Gangwon proposed the post-Olympics use of the facilities to the central government, it expected a deficit of KRW 7.4 billion (USD 6.6 million) per year, with only KRW 2.8 billion (USD 2.5 million) available from hosting the national team training ground and various competitions. According to Gangwon Provincial Office [85], Gangwon Province incurred debts ranging from KRW 860.5 billion (USD 777.9 million) to KRW 991.2 billion (USD 893.7 million) during the preparation period for the Olympics, and issued local bonds exceeding the amount of local bonds issued from 2013 to 2017. Given the cost of restoring Mt. Gariwang and managing the operation of the Olympic facilities, the issuance of additional local bonds by Gangwon Province is expected as additional funding is needed. 


\subsection{Evaluation of the Implementation of the Social Legacy}

\subsubsection{Local Community and Human Resources}

It is clear that the human resources created by this participation in the Olympics is the social legacy of the PyeongChang Olympics. The Olympic experience of Gangwon residents from hosting the PyeongChang Olympics remains an important human resource that can also contribute to the development of winter sports in South Korea beyond Gangwon Province. An interviewee, who worked both in the Olympics Games in Seoul in 1988 and PyeongChang in 2018, stated:

After all, every part of the Olympics is run by a person. I think the people who worked at the PyeongChang Olympics will be important human resources for Korea. These people are the human infrastructure of the Republic of Korea and can be fully utilized for other future events in Korea. In fact, my colleagues who worked with me at the 1988 Seoul Olympics became executives at the International Sports Federation and led the domestic sports industry. I think it could be an opportunity for Korea to develop winter sports through the human resources of the PyeongChang Olympics (Interviewee 10, 2019).

As a strategic approach of Gangwon Province, the PyeongChang Olympics provided an increase in the number of volunteering opportunities to promote a sense of community and regional identity among the Gangwon people. A Gangwon official who worked with POCOG, said:

PyeongChang received the support of 93 percent of Gangwon residents. I think the support from these local residents is the foundation for a successful Olympics. Without the participation of local residents, the Olympics is just a competition for elite sports. The preparation for the Olympics is important, but the support of local residents is more important. Also, a successful Olympics can be held only when national consensus is prioritized and local participation is high, rather than government-led Olympics (Interviewee 09, 2019).

Therefore, it is clear that the hosting of the PyeongChang Olympics created strong human resources in Gangwon Province. This can be said to have contributed greatly to the development of the local identity of Gangwon Province residents, whose pride as Gangwon citizens was the result of successfully hosting international events. According to a survey, more than half of the respondents (55.8\%) said they were proud to be Gangwon citizens because of the PyeongChang Olympics [86]. Additionally, Gangwon residents' experience of participating in the PyeongChang Olympics directly and indirectly is expected to help them host future events in Gangwon Province.

\subsubsection{Winter Sports Development}

Two interviewees who have been deeply involved in Korean winter sports, both believed that the good performance of the South Korean national team resulted from a long-term strategy (Interviewee 04, 2019; Interviewee 05, 2019). South Korea's long-term strategy for winter sports development flourished in PyeongChang. There is no doubt that the strategy of developing winter sports is the driving force behind South Korea's success in the PyeongChang Olympics. Drive the Dream II was a strategy to strengthen the competitiveness of winter sports by spending a total of KRW 550 billion (USD 495.9 million) over seven years in time for hosting the 2018 PyeongChang Olympics [75]. In this strategy, the central government provided a budget for three years after its inception to promote the creation of winter sports teams in less popular sports such as skiing, biathlon and luge. 
As a result, South Korea had the best Winter Olympics ever at the PyeongChang Olympics. South Korea has set a new record for winning the most medals ever with a total of 17 medals, with five golds, eight silvers and four bronzes. The most important thing to notice is that Korea has won a variety of medals in disciplines that have never been in medal contention. As shown in Table 2, in addition to its image as a traditional skating powerhouse, the Republic of Korea has shown outstanding performance in winter sports where Asian countries have been weaker.

Table 2. The List of the First Winter Olympic Medals of South Korea in PyeongChang.

\begin{tabular}{ccc}
\hline Disciplines & Type & Note \\
\hline $\begin{array}{c}\text { Skeleton for men } \\
\text { Curling for women }\end{array}$ & Gold & $\begin{array}{c}\text { The first gold medal in Winter Olympics' history } \\
\text { for South Korea other than for skating }\end{array}$ \\
$\begin{array}{c}\text { Snowboarding } \\
\text { Men's Parallel giant slalom } \\
\text { Bobsleigh-Four-man }\end{array}$ & Silver & $\begin{array}{c}\text { The Asian nation's first advance to the finals } \\
\text { The first South Korean Olympic medal on snow }\end{array}$ \\
\hline
\end{tabular}

One of the main reasons is explained by the director of international co-operation at Korean Sports and Olympic Committee (KOC), who stated that:

The level of the host country's sports is very important to the success of the Olympics. Gilbert Felli, IOC Olympic Games Executive Director, asked the KOC to submit a strategic plan on how it will achieve the development of winter sports in Korea in the PyeongChang Olympics within six years. So, the KOC prepared a strategy for two years also known as Drive the Dream II. As a result of this strategic and systematic plan, South Korea won Olympic medals in snowboarding, curling, bobsleigh and skeleton which we have never won a medal in before (Interviewee 05, 2019).

Additionally, the great facilities of the Olympic venues have contributed to the development of winter sports in South Korea. One member of the Korea Sport and Olympic Committee discussed this in detail:

Actually, we didn't meet 100 percent of our initial goals. We were aiming for fourth place overall and 20 medals. In fact, we have found possibilities in events that we have not won a medal in so far. In skiing, Lee Sang-ho won a medal and Yoon was able to establish himself as the world's No. 1 as well as winning a gold medal. When did we win a medal in the bobsleigh competition? The reason why the athletes could score well was by setting up the facilities a year before the Olympics and training there. This gives the athletes a place to try to improve their performance (Interviewee 04, 2019).

\subsubsection{Inter-Korean Relations}

It is clear that the PyeongChang Olympics gave new impetus to inter-Korean relations in many respects. First, North Korea's participation has provided an opportunity to spread Olympism, the essential philosophy of the Olympic Games, which is a global sports festival. The Peace Olympics, in which the two Koreas participated together on the divided Korean Peninsula, practised world peace through sports as the ultimate goal of Olympism. Even before the Games were held, the safety of the games was questioned due to security concerns on the Korean Peninsula caused by North Korea's nuclear weapons development. There were signs that France could boycott the PyeongChang Games. France's sports minister, Laura Flessel, said the French team may not participate in the PyeongChang Olympics if the security was not guaranteed due to inter-Korean tensions [87]. In line with this perspective, some countries in Europe also expressed concern about the unstable situation on the Korean Peninsula. However, North Korea's participation in the Olympics was able to dispel such safety concerns on the Korean Peninsula and proceed with the Olympics of harmony without a boycott due to safety concerns. Thomas Bach, who is 
president of the IOC, delivered the speech at the opening ceremony of the PyeongChang Olympics stating: 'Now in PyeongChang, the athletes from the teams of the Republic of Korea and the Democratic People's Republic of Korea, by marching together, send a powerful message of peace to the world' [88]. The participation of the unified women's ice hockey team with members from South and North Korea can be said to be close to the world peace in sport that the IOC ultimately seeks.

Secondly, the North's participation was a catalyst for restoring severed inter-Korean relations. The inter-Korean communication channel, which had been cut off two years earlier, was restored to Panmunjom on 3 January 2018. The fact that the inter-Korean communication channel, which had been suspended following the closure of the Kaesong Industrial Complex in North Korea, was reopened is full of meaning. In addition to the symbolism that the channel for inter-Korean dialogue is open all the time, the possibility of communication has prevented misunderstandings between the two countries, making it possible to prevent accidental military clashes between the two countries [89].

Finally, the PyeongChang Olympics was an opportunity for South Korea to gain soft power [27]. Hosting the 1988 Seoul Summer Olympic Games was a successful soft power strategy to discard its national image as one of the poorest countries with the memories of war and to celebrate its transformation to a successful country. South Korea's soft power strategy through the PyeongChang Olympics, the first of its kind in 30 years since the Seoul Olympics, has boosted the nation's image by easing inter-Korean relations. Moreover, the PyeongChang Winter Games also boosted international diplomacy through inter-Korean talks and strengthened the political support base in South Korea.

The PyeongChang Olympics, as part of South Korea's soft power strategy was an opportunity for South Korea to update South Korea's international image. The reconciliatory mood between the two Koreas projected the image of South Korea as a safer country. According to the Ministry of Unification [89], the improvement in South Korea's international image has helped stabilize the South Korean economy. In the wake of North Korea's military provocations in 2016 and 2017, interest rates, exchange rates, and credit default swap premiums rose and stock prices and foreign investment declined. The easing of inter-Korean tensions caused by the PyeongChang Olympics affected economic stability in 2018. In addition, international awareness of the PyeongChang Olympics and subsequent inter-Korean summits at Panmunjom was very positive. According to the Korean Culture and Information Service [90], more than 70 percent of the respondents said that both the PyeongChang Winter Olympics and the inter-Korean summit had positive effects, while 3.6 percent and 3.3 percent said they had negative effects, respectively. In the case of the inter-Korean summit, the external factors to be considered, such as political and diplomatic issues, are not as positive as the PyeongChang Olympics.

The continuing soft power of the PyeongChang Olympics has led to summit talks between North Korea and the United States after successfully leading three rounds of interKorean talks. Moreover, it built a diplomatic bridge between North Korea and the USA. In fact, there have been three inter-Korean summits and a North Korea-USA summit as a result of Olympic diplomacy through the PyeongChang Games. The diplomatic role played by South Korea, especially president Moon Jae-in's diplomatic ability, which led North Korea to the summit talks with the United States through three inter-Korean summits, has drawn global attention to South Korea as a negotiator. Campbell [91] reported that 'Moon Jae-in aims to be the South Korean leader who can deal with Kim Jong Un'.

In 2017, North Korea's nuclear test also worsened relations between the two Koreas, but relations with the United States were at their worst. Whereas North Korea called President Trump a 'psychopath', President Trump also warned North Korea that it would face 'fire and fury'. In 2017, South Korea, North Korea and the U.S. had such a bad relationship, but the PyeongChang Olympics held inter-Korean talks and the U.S.-North Korea talks. I think this is the biggest social legacy of the PyeongChang Olympics (Interviewee 03, 2019). 
The hosting of the PyeongChang Olympics also played a role in strengthening the political base of the South Korean president nationally. The successful hosting of the Olympics boosted his approval rating to 69.1 percent, up 8.3 percent from 60.8 percent before the PyeongChang Winter Olympics. Moreover, his approval rating also soared to 77.4 percent after the inter-Korean summit [92].

\subsection{Evaluation of the Implementation of the Environmental Legacy}

The most controversial part was the Jeongseon Alpine Skiing Resort located on Mt. Gariwang. The Jeongseon Alpine Skiing Resort initially caused conflicts between Gangwon Province and the central government over the location selection. Additionally, many PyeongChang Olympic stakeholders have been at odds over the original plan to restore it after the Olympics closed. The central and local governments are sharply divided on the issue of restoring the Jeongseon Alpine Stadium.

First of all, the central government's position is to fully restore the natural forests as originally planned. The stakeholders related to the issue are the Korea Forest Service and the Ministry of Environment from the central government, and Gangwon and Jeongseon, where the Jeongseon Alpine Centre is located. The forest of Mt. Gariwang, at the centre of the issue, was designated by the Korea Forest Service as a forest genetic resource reserve in 2008, where development of the area is restricted under the Management of Mountainous Districts Act. However, the special provision for the development of the forest genetic resource reserve under the 'Special Act on Support for the 2018 PyeongChang Winter Olympics and Paralympic Winter Games' allowed the Korea Forest Service to build Jeongseon Alpine Centre on Mt. Gariwang in 2013. It included 78 hectares of a total of 2475 hectares (about 3 percent) on Mt. Gariwang that have been removed from the protected area [93]. The treaty stipulated by the Korea Forest Service at the time of the convention focused on the restoration plan after the closing of the Olympics, although it inevitably damages the forests as follows:

Restoration of damaged areas should be carried out as a top priority in order to recover the natural nature of the area as soon as possible after hosting the Winter Olympics, and the results should be presented in the Environmental Impact Assessment Report after reviewing various measures to implement them in detail ... Since the selection of a site for the project was made based on the assumption that the ecological areas such as the forest genetic resource reserve were restored during the site selection phase of the project, specific restoration measures after the competition to implement them should be prepared and presented [94].

As such, the Ministry of Environment advised Gangwon Province to come up with concrete measures to restore the damaged areas after the Winter Olympics, but the original version of the environmental impact assessment submitted by the Gangwon provincial government did not include specific directions for the restoration. On 27 March 2014, a conditional permit for the use of mountain areas for Jeongseon Alpine Centre was finally granted by the Korea Forest Service without a definite plan for restoration with nominal details:

- $\quad$ To be reviewed by the Central Mountain Management Committee by submitting a restoration plan including post-use planning before the Winter Olympic Games.

- Organization of forest ecological restoration centres or committees that can be monitored for continuous restoration [95].

From an environmental perspective, it is clear that Gangwon Province expressed an irresponsible attitude toward the environment. During the PyeongChang Olympics preparation period, the central government asked Gangwon several times to state in the action plan how it would restore the alpine centre, but the Gangwon local government did not provide any specific plans. This is because Gangwon Province approached the Alpine Centre in the context of regional economics. As explained by a Gangwon official, who was involved in the PyeongChang Olympics: 
We (Gangwon Province) need to restore the Alpine Centre to a forest genetic resource reserve. However, we invested more than 200 billion Won to build slopes, gondolas and roads. We don't have an exact budget yet to restore it, but it will cost us more than the cost of building the Alpine Centre. So we think that if we leave a gondola and a road, we can use the view from Mountain Gariwang to create a great value added, such as mountain tourism and an eco-experience centre (Interviewee 07, 2019).

A member of the POCOG claimed that despite much environmental criticism of the Jeongseon Alpine Centre, the venue was fully appraised for environmental impacts and was of great value as an Olympic Legacy:

The views of the central government and Gangwon Province are very different.

Basically POCOG is not in charge of this legacy, but I think Mountain Gariwang should be left with much of it as a tourist resource. Even if we invest 200 billion Won again to restore the construction, we will not be able to restore it. In fact, it's not as bad as environmental groups claim. From the design stage, natural damage was minimized. For the first time in the history of the Olympics, it was built by integrating the men's and women's courses and minimizing environmental damage by repositioning them from Jungbong to Habong (Interviewee 08, 2019).

Jeongseon is one of the three host cities of the PyeongChang Olympics, where no legacy plan was put in place because only one Jeongseon Alpine Centre existed. From the perspective of the local government, it was keen to boost the sluggish local economy through the Olympic legacy created through the Olympics. A study on the basic planning of Jeongseon County's winter Olympic legacy established in 2015 showed that Jeongseon County was planning to revitalize the northern region of Jeongseon through the use of an Alpine Centre [96].

The cause of this conflict between central and local governments is the excessive business progress of the Olympics and the absence of an organization that can mediate when institutions are in conflict. The plan for the location of Olympic venues in the PyeongChang bid book should have been preceded by a national-level discussion on the selection of the Olympic venue regardless of whether an Olympics is taking place or not, especially in the case of an Alpine Centre whose location selection is important due to the characteristics of the sport. Completion of the Alpine Centre was imperative for the hosting of the FIS Ski World Cup, a test event scheduled for February 2016. However, with construction delayed due to environmental damage, discussions between the Korea Forest Service and Gangwon Province were completed without any concrete plans. In addition, a mediation body was needed to reconcile the conflicts between the central and local government agencies, even though the Ministry of Environment has repeatedly stated that the environmental impact assessment submitted by the Gangwon provincial government does not have any specific plans for restoration. This has left not only the future of the stadium but also the future of Mt. Gariwang in doubt, as the central government's administrative incompetence and also the impatience of Gangwon Province have only valued the hosting of the Olympics.

\section{Discussion}

This paper has attempted, through the example of sustainable legacy strategy of PyeongChang 2018 Winter Olympics, to demonstrate the actual outcome of PyeongChang's plan to leave behind a sustainable legacy. It also demonstrated the practical problems that caused the PyeongChang Olympics to not leave behind the sustainable Olympic legacy as originally planned.

First, through the PyeongChang Olympics, Gangwon Province and South Korea achieved their strategic goals. Gangwon Province, which has lagged behind the balanced development of South Korea, sought comprehensive development of Gangwon Province with the hosting of the PyeongChang Olympics. For transportation infrastructure, more than twice the budget spent on the PyeongChang Olympics was spent on the development 
of transportation infrastructure, including high-speed trains and expressways that connect Gangwon Province to Seoul. The aim of the transport network was not only to link the west and east of South Korea, but also to lower the psychological barrier surrounding Gangwon Province. In this regard, Gangwon is taking an opportunity to promote a logistic hub in Northeast Asia as Gangwon's next strategic goal. Those benefits of PyeongChang Games correspond with the literature, suggesting that hosting sports mega-event is an effective tool for promoting regional development [23,97].

The Olympic venues of the PyeongChang Games are also the result of the strategic goals of the Gangwon. Gangwon has established itself as the mecca of winter sports in South Korea, in renown and in reality, through the PyeongChang Olympics. As Chalip and Costa [30], Brown, Chalip, Jago and Mules [31] and Smith [98] stated, hosting sports mega-events contributed to enhancement of the destination image in terms of tourism. The local government is taking the opportunity to develop a centre of winter sports through the Olympic venues, a legacy of the PyeongChang Olympics. In addition, Gangwon Province has lagged behind the balanced development of the Republic of Korea, with Gangwon residents having a relatively low regional identity. The positive impacts of sports megaevents for local residents is an enhancement of their community pride and quality of life, directly or indirectly [99]. As a strategic goal, Gangwon Province planned to increase the regional identity of its citizens through the Olympics. Gangwon citizens who participated in the PyeongChang Olympics directly or indirectly could see their pride for Gangwon Province rise. Moreover, Gangwon residents who participated in the Olympics themselves could be used in various future international events as human infrastructure. In this context, it is clear that Gangwon achieved the strategic goals they had originally planned. The sports-related infrastructure and human resources gained from hosting the Olympics will also contribute to the subsequent following events, which will be the starting point for Gangwon Province to develop in the future, not just a one-time event. South Korea also had the best performance ever at the PyeongChang Olympics. It was the Republic of Korea's strategic approach to promote the development of winter sports in the wake of the PyeongChang Olympics, in relation to the winter sport development project that began in 2011. It is also a great outcome for the PyeongChang Olympics that South Korea won medals in several sports that have never even been able to reach the medal table.

In addition, the factors that posed an obstacle to the implementation of the sustainable legacy plan for the PyeongChang Olympics were analysed in the context of the South Korea. The main obstacle to the sustainability of the PyeongChang Olympics was the lack of a clear plan for post-Games use of Olympics venues and conflicts of interest among stakeholders of the PyeongChang Winter Games. First, the PyeongChang Olympics hampered its sustainability through several changes in location and design in the construction of Olympic venues. These frequent changes created constraints in the planning of the post-utilisation of Olympic venues. The post-Games use of Olympic venues is likely to degenerate into a 'white elephant' that economically torments the Republic of Korea as well as Gangwon Province. Notwithstanding, Gangwon Province designated the post-Games use of Olympic venues in the bid file, and there are still three Olympic venues that have not yet decided upon the subject of their managing body.

Second, there was lack of communication between PyeongChang Olympic stakeholders. There were opportunities to enhance the PyeongChang Olympics' economic sustainability through venue-sharing with other countries and cities, but South Korea and Gangwon refused all requests for venue-sharing. However, it is difficult to dismiss this simply as regional selfishness. If the IOC, the POCOG, or the National Olympic Committee had smoothly communicated and started consultations before construction began, the venue-sharing could have dramatically reduced the financial burden of the PyeongChang Olympics and improved economic sustainability. In addition, during the course of the stadium construction, the cost of construction was increased due to a lack of communication with the host city, Gangwon Province, and each IFs. This supports the work conducted 
by Chappelet [100], that there is no clear definition of the relationship between essential Olympic stakeholders.

The third issue was the conflict between local and central governments. The central government, the Ministry of Strategy and Finance, the Ministry of Culture and Tourism and the local government, and Gangwon Province were often at odds over the budget for the Olympics and the post-utilisation of Olympic venues. The cause of the conflict is the lack of a clear budget plan from the Olympic bid phase. Additionally, an environmental issue was the natural damage to Mt. Gariwang, where the alpine stadium was built. Some natural damage from the Games is inevitable, but restoration should be completed as originally planned. However, Jeongseon, where the alpine stadium is located, is strictly controlled from the perspective of regional development. Jeongseon insists on retaining it, not demolishing it. On the other hand, the results are still unclear as of 2019, as the central government insists on restoring the alpine stadium as originally planned.

\section{Limitation and Future Research Line}

The limitation of this study is that the proposed improvement in sustainability of sports mega-events may depend on the government and political system of the host country. The role of central government is paramount in carrying out national projects such as the Olympics. In the case of the PyeongChang Olympics, conflicts existed between central and local governments because the bid was won under the initiative of the local governments and then became a national project for central government. However, if a strong central government were to oversee all aspects from planning to implementing the Olympic Games, there would be less to do in terms of its strategy to leave a sustainable legacy, as suggested in this study. In the case of the 1988 Seoul Olympics, there were fewer conflicts among stakeholders and fewer additional external factors than at other Olympics regarding leaving an Olympic legacy due to the strong leadership of the central government [101]. In line with this perspective, an integrated study on sustainability of three Olympics, held and will hold (PyeongChang 2018, Tokyo 2021, and Beijing 2022) may be a meaningful line of research. The three countries are located in Northeast Asia, with similar traits and ethnic backgrounds, but the differences are also very clear. The study of the sustainability of the Olympics leading to a series of Olympics in nearby provinces will be an opportunity to recognise the characteristics of East Asia's sustainability, which follows from its government and political system.

\section{Conclusions}

This article has set out to provide an analysis of actual outcomes in the implementation of a legacy strategy of sports mega-events from the sustainability standpoint and to illuminate the key issues in legacy strategy implementation. As a result, in terms of the economic legacy, there were differences in the post-Games use of the Olympic venues and the amount of government funding for the PyeongChang Olympics. In terms of social legacy, the hosting of PyeongChang boosted the soft power of South Korea caused by North Korea's unexpected participation. Finally, the environmental legacy section concerned the issue of the retention and restoration of Mt. Gariwang, where the alpine centre was set up. The sustainability of the Olympics is a theme that takes into account economic, social and environmental aspects. However, with the environmental aspects of sustainability highlighted, research on other parts of sustainability (the economic and social legacies from the Olympics) has been conducted as an independent study, not as a topic of sustainability. Since the Olympics leave a sustainable legacy in harmony with the economic, social and environmental pillars, the main study, which analysed the three pillars of sustainability of the previous Olympics, is meaningful. 


\section{Managerial Implications}

This study provides several important academic and practical contributions that expand our knowledge about sustainability on sports mega-events. First, it is essential to establish in advance a definite plan through stakeholder consultation. It can be seen that the primary goal that local governments want to pursue through hosting the Olympics is to fund central government. With such financial support from the central government, local governments build the most urgent part of the infrastructure. In the case of sporting events without pre-planning, several examples of harming sustainability can be found at the PyeongChang Olympics. It can be seen that there were many conflicts throughout the Olympic process, from conflicts between the central and local governments through the amount of government funding immediately after the decision to host the Games, to conflicts related to government subsidies for managing the Olympic venues after the closing ceremony. A very high proportion of the costs in the Olympic budget is allocated to construction. In terms of the post-Games use of the Olympic venues, the occurrence of a 'white elephant' can be found not only in PyeongChang's case but also in previous Olympics.

Second, it is important to communicate actively and clearly among stakeholders related to sports mega-events for sustainability. The Olympic Games are a mega-event involving various stakeholders and interacting organically under the IOC's coordination. In the case of the PyeongChang Olympics, however, a lack of communication was revealed. Although the PyeongChang Olympics were able to secure sustainability through venue sharing with other countries and cities, it was decided to be held without venue sharing due to the lack of communication between respective stakeholders. In addition, even in the construction of Olympic venues it was confirmed that additional costs were incurred due to the lack of communication with Gangwon Province, which was in charge of construction, and with each IF. To prevent this, active communication between each stakeholder should have taken place throughout the entire Olympic process.

Finally, stricter management and regulation will be needed for the environmental legacy. PyeongChang hosted $\mathrm{O}_{2}$ Plus Green Olympics. However, the issue that remained afterwards was the conflict between the central and local governments over the restoration and maintenance of the alpine skiing centre. PyeongChang's case shows that even though the restoration plan existed, it was difficult to implement the restoration plan if stakeholders had conflicting interests. Environmental sustainability is the most difficult of the three pillars of sustainability to restore. To improve this environmental sustainability, host countries must first map out at the bid stage a plan to minimise natural damage. Moreover, there is a pressing need for an independent agency, a third party that can mediate in the event of such conflict.

Author Contributions: H.-M.K.: Conceptualization, methodology, software, investigation, resources, data curation, writing — original draft preparation. J.G.: validation, writing-review and editing, supervision. Both authors have read and agreed to the published version of the manuscript.

Funding: This research received no external funding.

Institutional Review Board Statement: The study was conducted according to the guidelines of the Declaration of Helsinki, and approved by Ethics Committee of Manchester Metropolitan University (protocol code 5400 and 02/05/2019).

Informed Consent Statement: Informed consent was obtained from all subjects involved in the study.

Data Availability Statement: Not applicable.

Conflicts of Interest: The authors declare no conflict of interest. 


\section{Appendix A}

\begin{tabular}{|c|c|}
\hline No & Research Questions \\
\hline 1 & $\begin{array}{l}\text { How would you describe that bidding process of PyeongChang } 2018 \text { Winter Games } \\
\text { in terms of sustainability? }\end{array}$ \\
\hline 2 & How do you consider the sustainability plan for PyeongChang? \\
\hline 3 & What strategies are used for sustainable legacy for the South Korea? \\
\hline 4 & $\begin{array}{l}\text { What is the most essential dimension of sustainability legacy plan among economy, } \\
\text { society and environment? }\end{array}$ \\
\hline 5 & What is the progress of the sustainable legacies of PyeongChang so far? \\
\hline 6 & Can you explain to me what the problem about bidding process were? \\
\hline 7 & What is the difference between bid book and actual realization so far? \\
\hline 8 & What part of the sustainability plan in bid book was the most difficult to implement? \\
\hline 9 & $\begin{array}{l}\text { What's the relationship between the PyeongChang Organizing Committee and } \\
\text { South Korea \& local Government? or other organization? }\end{array}$ \\
\hline 10 & What are the problems to realize the PyeongChang bidbook? \\
\hline 11 & $\begin{array}{l}\text { Could you suggest what strategies should be taken to realize sustainable legacy? If } \\
\text { the next sports mega-events is held in South Korea? }\end{array}$ \\
\hline
\end{tabular}

\section{References}

1. Preuss, H. Event legacy framework and measurement. Int. J. Sport Policy Politics 2019, 11, 103-118. [CrossRef]

2. Grix, J.; Brannagan, P.M.; Wood, H.; Wynne, C. State strategies for leveraging sports mega-events: Unpacking the concept of 'legacy'. Int. J. Sport Policy Politics 2017, 9, 203-218. [CrossRef]

3. MacAloon, J.J. Agenda 2020 and the Olympic Movement. Sport Soc. 2016, 19, 767-785. [CrossRef]

4. Girginov, V.; Hills, L. The political process of constructing a sustainable London Olympics sports development legacy. Int. J. Sport Policy 2009, 1, 161-181. [CrossRef]

5. IOC. Olympic Agenda 2020: 20+ 20 Recommendations. Available online: https://stillmed.olympic.org/media/Document\%20 Library/OlympicOrg/Documents / Olympic-Agenda-2020/Olympic-Agenda-2020-20-20-Recommendations.pdf (accessed on 12 November 2018).

6. Ok, G.; Ha, N. Beyond all barriers: The significance of the 1988 Seoul Olympics. In The Olympics in East Asia: Nationalism, Regionalism, and Globalism on the Center Stage of World Sports. New Haven: Council on East Asian Studies; Yale University: New Haven, CT, USA, 2011; pp. 95-108.

7. Kim, J. Pyeongchang Annals, 20-Year Story of the Winter Olympics; ISAE Books: Incheon, Korea, 2019.

8. Perić, M. Estimating the perceived socio-economic impacts of hosting large-scale sport tourism events. Soc. Sci. 2018, 7, 176. [CrossRef]

9. Massiani, J. Assessing the economic impact of mega events using Computable General Equilibrium models: Promises and compromises. Econ. Model. 2018, 75, 1-9. [CrossRef]

10. Kim, H.-D. Images of stakeholder groups based on their environmental sustainability linked csr projects: A meta-analytic review of korean sport literature. Sustainability 2017, 9, 1586. [CrossRef]

11. Schmidt, C.W. Putting the earth in play: Environmental awareness and sports. Environ. Health Perspect. 2006, 114, A286. [CrossRef] [PubMed]

12. Hayes, G.; Horne, J. Sustainable development, shock and awe? London 2012 and civil society. Sociology 2011, 45, 749-764. [CrossRef]

13. VanWynsberghe, R.; Derom, I.; Maurer, E. Social leveraging of the 2010 Olympic Games: 'Sustainability' in a City of Vancouver initiative. J. Policy Res. Tour. Leis. Events 2012, 4, 185-205. [CrossRef]

14. Müller, M. (Im-) Mobile policies: Why sustainability went wrong in the 2014 Olympics in Sochi. Eur. Urban Reg. Stud. 2015, 22, 191-209. [CrossRef]

15. Gaffney, C. Between discourse and reality: The un-sustainability of mega-event planning. Sustainability 2013, 5, 3926-3940. [CrossRef]

16. Hopwood, B.; Mellor, M.; O’Brien, G. Sustainable development: Mapping different approaches. Sustain. Dev. 2005, 13, 38-52. [CrossRef]

17. Adger, W.N.; Jordan, A. Governing Sustainability; Cambridge University Press: Cambridge, UK, 2009.

18. Kidd, C.V. The evolution of sustainability. J. Agric. Environ. Ethics 1992, 5, 1-26. [CrossRef] 
19. Drexhage, J.; Murphy, D. Sustainable development: From Brundtland to Rio 2012; United Nations Headquarters: New York, NY, USA, 2010; Volume 2010, pp. 9-13.

20. OECD. Local Development Benefits from Staging Global Events; 2008. Available online: https://doi.org/10.1787/9789264042070-en (accessed on 12 December 2018).

21. Dwyer, L.; Forsyth, P.; Spurr, R. Evaluating tourism's economic effects: New and old approaches. Tour. Manag. 2004, 25, 307-317. [CrossRef]

22. Ritchie, J.B. Assessing the impact of hallmark events: Conceptual and research issues. J. Travel Res. 1984, 23, 2-11. [CrossRef]

23. Gospodini, A. European cities in competition and the new'uses' of urban design. J. Urban Des. 2002, 7, 59-73. [CrossRef]

24. Gold, J.R.; Gold, M.M. Olympic cities: Regeneration, city rebranding and changing urban agendas. Geogr. Compass 2008, 2, 300-318. [CrossRef]

25. Kassens-Noor, E. Planning Olympic Legacies: Transport Dreams and Urban Realities; Routledge: London, UK, 2012.

26. Grix, J.; Brannagan, P.M.; Houlihan, B. Interrogating States' Soft Power Strategies: A Case Study of Sports Mega-Events in Brazil and the UK. Glob. Soc. 2015, 29, 463-479. [CrossRef]

27. Grix, J.; Houlihan, B. Sports Mega-Events as Part of a Nation's Soft Power Strategy: The Cases of Germany (2006) and the UK (2012). Br. J. Politics Int. Relat. 2014, 16, 572-596. [CrossRef]

28. Sánchez-Sáez, J.A.; Segado Segado, F.; Calabuig-Moreno, F.; Gallardo Guerrero, A.M. Measuring Residents' Perceptions of Corporate Social Responsibility at Small-and Medium-Sized Sports Events. Int. J. Environ. Res. Public Health 2020, $17,8798$. [CrossRef]

29. Babiak, K.; Wolfe, R. Determinants of corporate social responsibility in professional sport: Internal and external factors. J. Sport Manag. 2009, 23, 717-742. [CrossRef]

30. Chalip, L.; Costa, C.A. Sport event tourism and the destination brand: Towards a general theory. Sport Soc. $2005,8,218-237$. [CrossRef]

31. Brown, G.; Chalip, L.; Jago, L.; Mules, T. Developing brand Australia: Examining the role of events. Destin. Branding Creat. Unique Destin. Propos. 2004, 2, 279-305.

32. Sullivan, G.B. Collective emotions: A case study of South African pride, euphoria and unity in the context of the 2010 FIFA World Cup. Front. Psychol. 2018, 9, 1252. [CrossRef] [PubMed]

33. Higham, J. Commentary-sport as an avenue of tourism development: An analysis of the positive and negative impacts of sport tourism. Curr. Issues Tour. 1999, 2, 82-90. [CrossRef]

34. Hall, C.M. Hallmark Tourist Events: Impacts, Management and Planning; Belhaven Press: London, UK, 1992.

35. Getz, D. Event Management E Event Tourism; Cognizant Communication Corporation: New York, NY, USA, 1997.

36. Barker, M. Crime and sport events tourism: The 1999-2000 America's Cup. Sport Tour. Interrelat. Impacts Issues 2004, 14, 174.

37. Collins, A.; Jones, C.; Munday, M. Assessing the environmental impacts of mega sporting events: Two options? Tour. Manag. 2009, 30, 828-837. [CrossRef]

38. Pentifallo, C.; VanWynsberghe, R. Blame it on Rio: Isomorphism, environmental protection and sustainability in the Olympic Movement. Int. J. Sport Policy Politics 2012, 4, 427-446. [CrossRef]

39. Kelly, W.W. Asia pride, China fear, Tokyo anxiety: Japan looks back at Beijing 2008 and forward to London 2012 and Tokyo 2016. Int. J. Hist. Sport 2010, 27, 2428-2439. [CrossRef]

40. Chappelet, J.-L. Managing the size of the Olympic Games. Sport Soc. 2014, 17, 581-592. [CrossRef]

41. Flyvbjerg, B.; Stewart, A. Olympic Proportions: Cost and Cost Overrun at the Olympics 1960-2012; Saïd Business School Working Papers: Oxford, UK, 2012.

42. Zurawski, W. Krakow Citizens Reject 2022 Winter Olympic Bid; Reuters: Toronto, Canada, 2014.

43. Mol, A.P.; Zhang, L. Sustainability as global norm. The greening of mega-events in China. In Olympic Games, Mega-Events and Civil Societies: Globalization, Environment, Resistance; Hayes, G., Karamichas, J., Eds.; Palgrave Macmillan: London, UK, 2012; pp. 126-150.

44. Toohey, K. Olymp. Sustain. Report. Sport Participation; IOC Olympic Studies Centre: Lausanne, Switzerland, 2012.

45. Hall, C.M. Sustainable mega-events: Beyond the myth of balanced approaches to mega-event sustainability. Event Manag. 2012, 16, 119-131. [CrossRef]

46. Weiler, J.M.; Mohan, A. Catalyst, Collaborator, Connector: The Social Innovation Model of 2010 Legacies Now: Case Study; Legacies Now, 2010. Available online: https://www.2010andbeyond.ca/media/pdf/Catalyst_Collaborator_Connector_The_Social_Innovation_ Model_of_2010_Legacies_Now.pdf (accessed on 12 November 2018).

47. Holden, M.; MacKenzie, J.; VanWynsberghe, R. Vancouver's promise of the world's first sustainable Olympic Games. Environ. Plan. C Gov. Policy 2008, 26, 882-905. [CrossRef]

48. Davis, J. Futurescapes of urban regeneration: Ten years of design for the unfolding urban legacy of London's Olympic Games, 2008-2018. Plan. Perspect. 2018, 34, 877-901. [CrossRef]

49. LLDC. Your Sustainability Guide to Queen Elizabeth Olympic Park 2030; London Legacy Development Corporation: London, UK, 2012.

50. Parent, M.M. Evolution and issue patterns for major-sport-event organizing committees and their stakeholders. J. Sport Manag. 2008, 22, 135-164. [CrossRef] 
51. Elkington, J. Cannibals with Forks: The Triple Botton Line of 21st Century Business; Capstone Publishing Limited: Mankato, MN, USA, 1997.

52. Savitz, A. The Triple Bottom Line: How Today's Best-Run Companies are Achieving Economic, Social and Environmental Success-and How You Can Too; John Wiley \& Sons: Hoboken, NJ, USA, 2006.

53. Deegan, C. Implementing triple bottom line performance and reporting mechanisms. Charter 1999, 70, 40-42.

54. Willard, B. The New Sustainability Advantage: Seven Business Case Benefits of a Triple Bottom Line; New Society Publishers: Gabriola, BC, Canada, 2012.

55. Evans, S.; Vladimirova, D.; Holgado, M.; Van Fossen, K.; Yang, M.; Silva, E.A.; Barlow, C.Y. Business model innovation for sustainability: Towards a unified perspective for creation of sustainable business models. Bus. Strategy Environ. 2017, 26, 597-608. [CrossRef]

56. Spangenberg, J.H. Economic sustainability of the economy: Concepts and indicators. Int. J. Sustain. Dev. 2005, 8, 47-64. [CrossRef]

57. Alhaddi, H. Triple bottom line and sustainability: A literature review. Bus. Manag. Stud. 2015, 1, 6-10. [CrossRef]

58. Goel, P. Triple Bottom Line Reporting: An Analytical Approach for Corporate Sustainability. J. Financ. Account. Manag. 2010, 1, 27-42.

59. Dhiman, S. Products, people, and planet: The triple bottom-line sustainability imperative. J. Glob. Bus. Issues 2008, 2, 51-57.

60. Bryman, A.; Bell, E. Business Research Methods; Oxford University Press: New York, NY, USA, 2015.

61. Grix, J. The Foundations of Research; Palgrave Macmillan: London, UK, 2019.

62. Bryman, A. Social Research Methods; Oxford university press: New York, NY, USA, 2015.

63. Scott, J. A Matter of Record: Documentary Sources in Social Research; John Wiley \& Sons: Hoboken, NJ, USA, 1990.

64. May, T. Social Research, 4th ed.; McGraw-Hill Education: London, UK, 2011.

65. Gratton, C.; Jones, I. Research Methods for Sports Studies; Taylor \& Francis: Oxfordshire, UK, 2010.

66. Vromen, A. Debating Methods: Rediscovering Qualitative Approaches; Macmillan Education: London, UK, 2016.

67. Given, L.M. The Sage Encyclopedia of Qualitative Research Methods; Sage Publications: New York, NY, USA, 2008 ; Volume 2.

68. McNamara, C. General Guidelines for Conducting Interviews; 2009. Available online: https://managementhelp.org/ businessresearch/interviews.htm. (accessed on 8 February 2020).

69. Bowen, G.A. Document analysis as a qualitative research method. Qual. Res. J. 2009, 9, 27. [CrossRef]

70. Braun, V.; Clarke, V. Using thematic analysis in psychology. Qual. Res. Psychol. 2006, 3, 77-101. [CrossRef]

71. POBICO. PyeongChang 2018 Candidate City File PyeongChang Volume 1; PyeongChang Olympic Bid Committee: Seoul, Korea, 2010.

72. RIG. Comprehensive Development Strategy in Gangwon by Hosting PyeongChang 2018 Winter Olympic Games; Research Institute for Gangwon: Gangwon-do, Korea, 2011.

73. Shoval, N. A new phase in the competition for the Olympic gold: The London and New York bids for the 2012 Games. J. Urban Aff. 2002, 24, 583-599. [CrossRef]

74. Fredline, E. Host and guest relations and sport tourism. Sport Soc. 2005, 8, 263-279. [CrossRef]

75. KISS. Drive the Dream II-To Foster Winter Sports with "SMART Project"-(2012 2018); Korea Institute of Sport Science: Seoul, Korea, 2011.

76. POCOG. Creating a New Horizon for Sustainable 2018 PyeongChang Olympic and Paralympic Winter Games: Furthering Benefits to Human and Nature. Games; The PyeongChang Organizing Committee for the 2018 Olympic \& Paralympic Winter Games: PyeongChang, Korea, 2015.

77. Park, L.; Kim, J.; Kim, W. [PyeongChang Olympics D-200] Disgraced by 126.4 Billion Won Gangneung Ice Link; JongAng Ilbo: Seoul, Korea, 2017.

78. Korea Herald. IOC Eyes 12 Alternate Sites for Sliding Venue; Korea Herald: Seoul, Korea, 2014

79. Yoon, H.; Seung, H. Saving 113.7 Billion Won When Using Ice Hockey, Olympic Swimming Pool and Mokdong Ice Link; The Hankyoreh: Seoul, Korea, 2015.

80. Jun, J.-H. President Park Opposes Splitting PyeongChang Games; Korea Times: Seoul, Korea, 2014.

81. POCOG. 2016 Annual Report of Preparation for PyeongChang Olympics PyeongChang Organizing Committee for the 2018 Olympic $\mathcal{E}$ Paralympic Winter Games; The PyeongChang Organizing Committee for the 2018 Olympic \& Paralympic Winter Games: PyeongChang, Korea, 2017.

82. National Assembly of South Korea. SPECIAL ACT ON SUPPORT FOR THE 2018 PYEONGCHANG OLYMPIC AND PARALYMPIC WINTER GAMES; Tourism; National Assembly of South Korea: Seoul, Korea, 2014.

83. POBICO. PyeongChang 2014 Candidate City PyeongChang; PyeongChang Olympic Bid Committee: Seoul, Korea, 2006.

84. KDI. A Study on the Effective Post-Game Use of Olympic Venues; Korea Development Institute: Chungcheongnam-do, Korea, 2019.

85. Gangwon Provincial Office. 2018 Gangwon Province Finance Disclosure; Gangwon Provincial Office: Gangwon-do, Korea, 2018.

86. Kim, Y. Traffic Conditions Have Improved Significantly, but the Economic Impacts Are "Well..."; Gangwondomin Ilbo: Chuncheon, Korea, 2019.

87. Lough, R.J. Hyunjoo. France to Skip 2018 Winter Games if Security not Assured; Reuters: Toronto, ON, Canada, 2017.

88. Bach, T. Opening Ceremony of the Olympic Winter Games PyeongChang 2018 PyeongChang, 9 February 2018 FINAL ENGLISH. Available online: https://stillmedab.olympic.org/media/Document\%20Library/OlympicOrg/News/2018/02/openingceremony / President-speech-PyeongChang-2018-Opening-Ceremony.pdf (accessed on 11 December 2018). 
89. Ministry of Unification. Related to North Korea's Participation in the PyeongChang Winter Olympics Comprehensive Report; Ministry of Unification: Seoul, Korea, 2018.

90. Korean Culture and Information Service. 2018 National Image Survey Report; Korean Culture and Infomation Service: Seoul, Korea, 2019.

91. Campbell, C. The Negotiator; Time: New York, NY, USA, 2017.

92. Realmeter. Moon Jae-in Approval Rating Chart; Politic \& Society \& Economy Research, 2019.

93. Kim, H. The Present Status of Preservation and Restoration of "Forest Genetic Resource Reserve"; Korea Forest Service: Daejeon, Korea, 2013.

94. Wonju Regional Environmental Office. Environmental Impact Statement; Wonju Regional Environmental Office: Gangwon-do, Korea, 2013.

95. KICSD. Sustainability Assessment and Guidelines for the Sustainable International Competition in the PyeongChang Winter Olympics; Korea Institute Center for Sustainable Development: Seoul, Korea, 2018.

96. RIG. A Study on the Basic Planning of Jeongseon County's Winter Olympic Legacy Gangwon; Research Institute for Gangwon: Gangwon-do, Korea, 2015.

97. Müller, M. What makes an event a mega-event? Definitions and sizes. Leis. Stud. 2015, 34, 627-642. [CrossRef]

98. Smith, A. Reimaging the city: The value of sport initiatives. Ann. Tour. Res. 2005, 32, 217-236. [CrossRef]

99. Andereck, K.L.; Nyaupane, G.P. Exploring the nature of tourism and quality of life perceptions among residents. J. Travel Res. 2010, 50, 248-260. [CrossRef]

100. Chappelet, J.-L. From Olympic administration to Olympic governance. Sport Soc. 2016, 19, 739-751. [CrossRef]

101. Im, T.Y.I.; Kwon, H.; Han, B. Organizations in Olympic Governance: A Comparison between Olympic OrganizingCommittees for Seoul Olympics and Pyeongchang Olympics. Korean Assoc. Organ. Stud. 2016, 13, 149-182. 